\title{
Study on Human Ecological Factors Affecting Interpersonal and Intrapersonal Intelligence of Young Adolescents
}

\author{
Sumit Sheoran*, Sudha Chhikara and Sheela Sangwan
}

\author{
Department of Human Development and Family Studies, I.C. College of Home Science, \\ CCSHAU, Hisar, Haryana - 125004, India \\ *Corresponding author
}

\begin{tabular}{l} 
K e y w o r d s \\
$\begin{array}{l}\text { Multiple intelligence, } \\
\text { Parental involvement and } \\
\text { other human ecological } \\
\text { factors }\end{array}$ \\
Article Info \\
$\begin{array}{l}\text { Accepted: } \\
18 \text { October } 2018 \\
\text { Available Online: } \\
10 \text { November } 2018\end{array}$ \\
\hline
\end{tabular}

\section{A B S T R A C T}

Interpersonal intelligence ("people smart") is ability to see things from other people's point of view in order to understand how they think and feel. Whereas, Intrapersonal intelligence ("self-smart") is the ability to self-reflect, to understand inner feelings, dreams, relationships with others, and strengths and weaknesses. Ecological Systems Theory given by Urie Bronfenbrenner in 1940s focuses that there are five layers arranged from the closest to the individual to the farthest: the microsystem, mesosystem, exosystem, macrosystem and chronosystem. These all systems directly or indirectly affect the individual growth and development. Hence, the effect of these variables was studied along with Multiple Intelligence of the young adolescents. For this, 200 respondents in the age group of 12-14 years from both urban and rural area of Mahendergarh district of Haryana state were selected. Both interpersonal and intrapersonal intelligences of the respondents' were observed to be significantly associated with family size, parental education and residence location. It is clear from the research that the other microsystem variables had no significant association with both interpersonal and intrapersonal intelligences of the respondents.

\section{Introduction}

Over the past few decades, research in the ground of learning has led to the discovery of the Theory of Multiple Intelligences. The work on Multiple Intelligences commenced in the early 1980s with Howard Gardner, and the research still continues. Originally, this theory emerged from the cognitive research, which states that the extent to which scholars possess different kinds of minds and therefore discover, memorize, execute and understand in different ways. According to Multiple Intelligence Theory, there are nine wellknown intelligences: bodily-kinesthetic, existential, interpersonal, intrapersonal, linguistic, logical-mathematical, musical, naturalistic and visual spatial. In greater detail, the theory entails that "all individuals are able to perceive the world through language, logical-mathematical psychoanalysis, spatial illustration, musical thinking, by the use of their bodies to solve problems or to make things, an understanding of other individuals' 
emotions and an understanding of themselves. Thus, in today's world, the need of interpersonal (social reflection) and intrapersonal (self-reflection) intelligences is crystal clear. As interpersonal intelligence is the talent to understand and interact effectively with others. It also involves effective verbal and nonverbal communication (facial and hand gestures), the ability to note dissimilarities among others, sensitivity to the moods and temperaments of others, and the ability to consider multiple perspectives. Teachers, motivational speakers, counselors, social workers and political leaders exhibit interpersonal intelligence at an enhanced level. Adolescents with this kind of intelligence are leaders among their peer groups and seem to understand others' feelings and inner motives. Intra-personal intelligence can be defined as the competence to understand oneself and one's thoughts and feelings, and to utilize this knowledge in planning and directing one's life. Intra-personal intelligence involves not only an admiration of the self, but also of the human condition.

It is apparent in psychologists, spiritual leaders and philosophers. These young adults may be shy and introverts, but they are very well aware of their own feelings and are selfmotivated. Individuals differ is in the potency of their intelligences and the ways in which these intelligences combine to carry out different tasks, solve varied problems and excel in a variety of domains. Past researches have proved that distinguished instruction benefits all students, but must be offered by well-prepared, experience and knowledgeable teachers. This diversity, according to Howard Gardner, should influence the way people are educated. He further stated that these differences "challenge an historical educational system that assumes that everyone can learn the same materials in the same manner and that a uniform, universal measure suffices to check student learning."
Gardner goes on to say that as our conventional educational system heavily relies on linguistic intelligence as mode of instruction and assessment and, to a somewhat lesser extent, toward logical-quantitative intelligence modes as well. Even our society views children as "vital" members of society only if they are logically and linguistically intelligent and, "less vital" to those who are other kind of intelligent.

But, in today's world, where both parents are working, nuclear family system is prevailing, children are spending their most of time in day care centers, it becomes the most important and difficult thing to imbibe inter and intrapersonal skills to them. So that in the fast growing world, not only they can survive successfully but can also earn their livelihood by following their interest areas, whether it is politics or theosophical.

Agarwal and Suraksha (2017) organized a study with the rationale to investigate differences between male and female students with reference to different dimensions of Multiple Intelligence. The research findings revealed that female students possess more linguistic, spatial, musical, interpersonal, intrapersonal and existential intelligence than male students.

Advani and Hema (2016) conducted a study to investigate the effect of interpersonal intelligence based teaching strategy (IBTS) on students' academic achievement. The sample was divided as experimental and control group. The experimental group was taught through IBTS whereas the control group was treated with conventional teaching. To find out the effectiveness of IBTS over conventional teaching method, an academic achievement test on the science topics was administered. The results showed that students who were taught through IBTS scored higher than the other group. 
Gupta (2016) carried out study entitled "Effect of Family Variables on Multiple Intelligences of Secondary School Students of Gujarat State" to find out the individual potential of young adolescents in terms of their intelligences and the effect of family related factors on their intelligences. It was recorded that some of the family and environment related variables such as working status of parents, parents' qualification, joint family and nuclear family staying with and without siblings affect the intelligences of learner positively and some do not have any effect as given.

\section{Objectives}

To study the association of human ecological variables with interpersonal intelligence of the young adolescents.

To assess the association of human ecological variables with intrapersonal intelligence of the young adolescents.

\section{Materials and Methods}

The present study was conducted in Haryana state. Multi stage sampling procedure was followed to have the representative sample. Out of total backward districts of Haryana state one was taken randomly. For rural sample, one block was selected at random from the selected district. From selected block one village having Government High/Senior Secondary Schools and Private High/Senior Secondary Schools was taken purposively. Similarly, for urban sample, one Government High/Senior Secondary Schools and Private High/Senior Secondary School was taken randomly from the selected city.

\section{Selection of respondents}

A list of girl students in the age group of 1214 years was procured from both the selected schools of each area. A sample of 200 young adolescent girls was taken randomly from the list of selected schools of rural and urban areas. Out of 200 adolescent girls, 100 from urban and 100 from rural areas were selected randomly. This sample of 100 adolescent girls constituted of 50 girls each from Government and Private Schools.

\section{Instrument of the study}

The primary data was collected by using questionnaire-cum-interview schedule developed by Kaur, 2006. The tool consisted of nine subscales namely, linguistic, logical mathematical, bodily kinesthetic, visual spatial, interpersonal, intrapersonal, naturalistic and existential intelligences. This tool was selected as it is reliable, its retest reliability coefficients for nine components were in the range of 0.63 to 0.86 and for inter observer reliability coefficients it was ranging from 0.61 to 0.90 . Tool is also valid as its content validity ratio was ranging from 0.2 to 0.8 and its cross validity was ranging from 0.02 to 3.49. Scoring pattern used for interpersonal and intrapersonal intelligences is given in Table 3 .

\section{Analysis of the data}

Chi square test of independence was used to measure the degree of association between dependent and independent variables.

\section{Results and Discussion}

Table 1 shows the association of microsystem variables on interpersonal intelligence of the respondents. Results revealed that several aspects of interpersonal intelligence were significantly associated with various microsystem variables, whereas others were not. Family size was observed to be significantly associated with (15.53) interpersonal intelligence of the respondents'. 
Table.1 Association of human ecological variables with interpersonal intelligence

\begin{tabular}{|c|c|c|c|c|c|}
\hline \multirow[t]{2}{*}{$\begin{array}{l}\text { Sr. } \\
\text { No. }\end{array}$} & \multirow[t]{2}{*}{ Variables } & \multirow{2}{*}{$\begin{array}{c}\text { Above } \\
\text { A verage } \\
\text { F }(\%)\end{array}$} & \multirow{3}{*}{$\begin{array}{l}\text { Average } \\
\text { F (\%) }\end{array}$} & \multirow{3}{*}{$\begin{array}{c}\text { Below } \\
\text { A verage } \\
\text { F (\%) }\end{array}$} & \multirow[t]{2}{*}{$\begin{array}{l}\text { Chi square } \\
\text { value }\end{array}$} \\
\hline & & & & & \\
\hline \multirow[t]{4}{*}{1.} & Family type & & & & \\
\hline & Nuclear & $24(12.0)$ & $31(15.5)$ & $54(27.0)$ & \multirow{3}{*}{5.08} \\
\hline & Joint & $11(5.5)$ & $23(11.5)$ & $56(23.0)$ & \\
\hline & Extended & - & - & $1(0.5)$ & \\
\hline \multirow[t]{4}{*}{2.} & Family size & & & & \\
\hline & Small(up to 4 members) & $24(12.0)$ & $32(16.0)$ & $42(21.0)$ & \multirow{3}{*}{$15.53 *$} \\
\hline & Medium(5-6 members) & $11(5.5)$ & $18(9.0)$ & $53(26.5)$ & \\
\hline & Large(more than 6 members) & - & $4(2.0)$ & $16(8.0)$ & \\
\hline \multirow[t]{4}{*}{3.} & Mothers' education & & & & \\
\hline & Illiterate & $26(13.0)$ & $33(16.5)$ & $39(19.5)$ & \multirow{3}{*}{$28.98 *$} \\
\hline & Primary to middle & $9(4.5)$ & $19(9.5)$ & $45(22.5)$ & \\
\hline & Graduate/PG & - & $2(1.0)$ & 27 (13.5) & \\
\hline \multirow[t]{4}{*}{4.} & Fathers' education & & & & \\
\hline & Illiterate & $19(9.5)$ & $22(11.0)$ & $26(13.0)$ & \multirow{3}{*}{$22.81^{*}$} \\
\hline & Primary to middle & $16(8.0)$ & $26(13.0)$ & $53(26.5)$ & \\
\hline & Graduate/PG & - & $6(3.0)$ & $32(16.0)$ & \\
\hline \multirow[t]{4}{*}{5.} & Family income per month (Rs.) & & & & \\
\hline & Up to 5000 & $17(8.5)$ & $26(13.0)$ & $54(27.0)$ & \multirow{3}{*}{1.64} \\
\hline & $5900-10000$ & $13(6.5)$ & $18(9.0)$ & $32(16.0)$ & \\
\hline & More than 10000 & $5(2.5)$ & $10(5.0)$ & $25(12.5)$ & \\
\hline
\end{tabular}

*Significant at 0.05

Note: Figures in the parentheses indicate percentage

Table.2 Association of microsystem variables with intrapersonal intelligence

\begin{tabular}{|c|c|c|c|c|c|}
\hline \multirow[t]{2}{*}{ Sr. No. } & \multirow[t]{2}{*}{ Variables } & $\begin{array}{c}\text { Above } \\
\text { Average }\end{array}$ & Average & $\begin{array}{c}\text { Below } \\
\text { Average }\end{array}$ & \multirow[t]{2}{*}{$\begin{array}{l}\text { Chi square } \\
\text { value }\end{array}$} \\
\hline & & $\mathbf{F}(\%)$ & $\mathbf{F}(\%)$ & $\mathbf{F}(\%)$ & \\
\hline \multirow[t]{4}{*}{1.} & Family type & & & & \\
\hline & Nuclear & $34(17.0)$ & 37 (18.5) & $38(19.0)$ & \multirow{3}{*}{3.46} \\
\hline & Joint & $33(16.5)$ & $23(11.5)$ & $34(17.0)$ & \\
\hline & Extended & - & - & $1(0.5)$ & \\
\hline \multirow[t]{4}{*}{2.} & Family size & & & & \\
\hline & Small(up to 4 members) & $35(17.5)$ & $36(18.0)$ & 27 (13.5) & \multirow{3}{*}{$10.92 *$} \\
\hline & Medium(5-6 members) & $29(14.5)$ & $19(9.5)$ & $34(17.0)$ & \\
\hline & Large(more than 6 members) & $3(1.5)$ & $5(2.5)$ & $12(6.0)$ & \\
\hline \multirow[t]{4}{*}{3.} & Mothers' education & & & & \\
\hline & Illiterate & $33(16.5)$ & $38(19.0)$ & 27 (13.5) & \multirow{3}{*}{$14.13^{*}$} \\
\hline & Primary to middle & 27 (13.5) & $18(9.0)$ & $28(14.0)$ & \\
\hline & Graduate/PG & $7(3.5)$ & $4(2.0)$ & $18(9.0)$ & \\
\hline \multirow[t]{4}{*}{4.} & Fathers' education & & & & \\
\hline & Illiterate & $20(10.0)$ & $25(12.5)$ & $22(11.0)$ & \multirow{3}{*}{$11.40^{*}$} \\
\hline & Primary to middle & $38(19.0)$ & $28(14.0)$ & $29(14.5)$ & \\
\hline & Graduate/PG & $9(4.5)$ & $7(3.5)$ & $22(11.0)$ & \\
\hline \multirow[t]{4}{*}{5.} & Family income per month (Rs.) & & & & \\
\hline & Up to 5000 & $33(16.5)$ & $33(16.5)$ & $31(15.5)$ & \multirow{3}{*}{3.38} \\
\hline & $5900-10000$ & $22(11.0)$ & $18(9.0)$ & $23(11.5)$ & \\
\hline & More than 10000 & $12(6.0)$ & $9(4.5)$ & $19(9.5)$ & \\
\hline
\end{tabular}

*Significant at 0.05

Note: Figures in the parentheses indicate percentage 
Table.3 Instrument of the study

Interpersonal Intelligence

Above average (21 and above)

Average (18-20)

Below average (17 and below)
Intrapersonal Intelligence

Above average (15 and above)

Average (12-14)

Below average (11 and below)
Codel Scoring Pattern

1

Significant associations were observed between parental education and interpersonal intelligence of the respondents' i.e., with mothers' education (28.98) and fathers' education (22.81). Results elucidates that the other microsystem variables (family size and monthly family income) had no significant association with interpersonal intelligence of the respondents' (Table 2).

It is apparent from the results that the other microsystem variables (family size and monthly family size) had no significant association with intrapersonal intelligence of the respondents.

Both interpersonal and intrapersonal intelligences of the respondents' were found to be significantly associated with family size and parental education. Other microsystem variables i.e. family type and monthly family income had no significant association with both interpersonal and intrapersonal intelligences of the respondents'. Research findings were also supported by the previous research results entitled "Effect of Family Variables on Multiple Intelligences of Secondary School Students of Gujarat State", which focused on the individual potential of young adolescents in terms of their intelligences and the effect of family related factors on their intelligences by Gupta (2016). It was concluded that some of the family and environment related variables such as working status of parents, parents' qualification, joint family and nuclear family staying with and without siblings affect the intelligences of learner positively and some do not have any effect as given. Activities such as working in small groups on a project, mentoring or teaching concepts to another student, conducting interviews, role playing historical or literary situations and team building exercises may be suggested to enhance interpersonal intelligence of the adolescents. Intrapersonal intelligence of the adolescents may be improved by various activities such as writing an autobiography, working independently, meditation and writing about which historical or literary figures they would want to be etc.

\section{References}

Advani, V., and Hema, G., (2016). Effect of Interpersonal Intelligence Based Teaching Strategies on Students Academic Achievement. The International Journal of Indian Psychology. Vol. 3 (4). pp: 23493429.

Agarwal, S., and Suraksha (2017). A Comparative Study of Multiple Intelligence among Male and Female Students of Class XI. International Journal of Advanced Research in Education and Technology (IJARET). Vol. 4 (1).

Gardner, H., (2006). Multiple Intelligences: New horizons. Basic Books: New York.

Gupta, S., (2016). Effect of Family Variables on Multiple Intelligences of Secondary School Students of Gujarat State. The International Journal of Indian Psychology. Vol. 3 (4) pp: 2349-3429.

\section{How to cite this article:}

Sumit Sheoran, Sudha Chhikara and Sheela Sangwan. 2018. Study on Human Ecological Factors Affecting Interpersonal and Intrapersonal Intelligence of Young Adolescents. Int.J.Curr.Microbiol.App.Sci. 7(11): 2416-2420. doi: https://doi.org/10.20546/ijcmas.2018.711.275 